\title{
Empirical modeling and determination of the grindability in stirred ball mills
}

\author{
Viktória Mannheim \\ Institute of Raw Material Processing and Environmental Process Engineering, \\ University of Miskolc \\ ejtviki@uni-miskolc.hu
}

\section{Örölhetőség meghatározása empirikus modellezéssel keverö- golyósmalmokban}

A diszperz rendszerek előállításánál az aprítás és az őrlés az egyik leggyakrabban alkalmazott technológiai művelet. Ma már bizonyított, hogy az őrlés a részecskeméret csökkenése mellett, az őrleményben mélyrehatóbb szerkezeti változásokat és kémiai átalakulásokat is előidéz. A finomőrlés során végbemenő anyagszerkezeti változások és mechanokémiai reakciók szempontjából a plasztikus (mikroplasztikus) deformáció létrejötte játszik fontos szerepet, ahol a részecske gyakorlatilag „hibahelymentessé” válik. A finomőrléssel elöállított termékek tulajdonságait az elsődleges és a másodlagos mechanokémiai folyamatok sebessége és mértéke határozza meg. Az örlési folyamatot az elsődleges folyamatok elősegítésével és a másodlagos folyamatok visszaszorításával lehet irányítani. Hazánkban, a finomőrlés hatékonyságának mechanokémiai kidolgozásában JUHÁSZ ÉS OPOCZKY $[1,2,3,4]$ ért el úttörő eredményeket. A finomőrléskor jelentkező mechanokémiai jelenségek kollerjáraton történő tanulmányozásával GÖMZE $[5,6,7]$ foglalkozott.
Az anyagoknak keverőmalomban történő őrölhetőségének megállapítása céljából kutatásaim során, egy saját tervezésủ laboratóriumi keverö-golyósmalommal végeztem ultrafinom nedves őrlési vizsgálatokat. Az őrlemény szemcseméret-eloszlásának becslése empirikus modell segítségével történhet. A keverőmalmi őrlési folyamat törvényszerü viselkedése két alapfüggvénnyel jellemezhető: az empirikus törési függvénnyel és az $x_{50}$ időbeli változását leíró $x_{50}=a \cdot t^{b}$ (mediánörlési idő) hatványfüggvénnyel. Az alapfüggvények paramétereinek az üzemjellemzőktöl $\left(\mathrm{n}, \mathrm{c}_{\mathrm{m}}, \varphi_{\mathrm{m}}, \mathrm{d}_{\mathrm{g}}\right.$ ). való függését reprezentáló empirikus függvények alkalmazásával az őrlemény szemcseméret-eloszlás jól megbecsülhető. Az elvégzett (nemlineáris paraméterbecslési) korrelációs eljárással kapott eredmények szerint, a törési függvény Rosin-Rammler függvénnyel, elegendő pontossággal közelíthető. A medián és a fajlagos őrlési munka közötti összefüggés valamennyi vizsgált anyagra azonos törvényszerüséget mutat, ahol az $m$ kitevő (meredekség) 0,2 konstans érték. A $C_{m i x}$ paraméter az örölhetőséget jellemző méröszám, amelynek alapján a keverőmalomban vizsgált anyagok örölhetőségének sorrendje (a könnyebben örölhetőtől a nehezebben őrölhető felé haladva): mészkő, andezit, gyöngyösoroszi meddő és pumicit.

\section{Introduction}

Producing of disperse systems, comminution and grinding are two of the most often applied technological processes. Nowadays it has already been proved that grinding besides decreasing of particle size causes structural and chemical changes too in he grinding material. With respect to structural changes and mechanochemical reactions in fine grinding, plastic deformation has an important role where the particle becomes practically „free of dislocation". The properties of products produced by fine grinding depend on the speed and the degree of the primary and secondary mechanochemical processes. The grinding process can be directed by helping of primary processes and reducing of secondary processes. In Hungary, JUHÁSZ and OPOCZKY $[1,2,3,4]$ reached pioneering results in mechanochemical working out of grinding's efficiency. GÖMZE $[5,6,7]$ investigated the mechanochemical processes on kollergang during the fine grinding. In my research, I applied a laboratory stirred ball mill for the investigation of fine grinding processes.

Stirred ball mills are used successfully for processing a great number of different very fine products in the ceramic, chemical, pharmaceutical, food, lacquer and paint industries. Recently, a variety of stirred ball mills have been developed and applied world-wide. Owing to their high efficiency, stirred ball mills have greatly replaced traditional systems, such as the roll mill for and the jet mill. It is designed for wet or dry ultrafine grinding. Ultrafine wet grinding with stirred ball mills has a wide range of applications.

In stirred ball mills the grinding effect in the grinding chamber is achieved by the energy input generated by the stirrer. The grinding media are moved by the rotation of an axial stirring device while the grinding cylinder is stationary. The particles are ground by pressure and friction between the moving grinding media. A widely accepted fact in ultrafine grinding is that the specific energy consumption $\left(E_{M}\right)$ is the main criterion for mills and for the particle size reduction. According to STEHR [8] the effect of the operating parameters: stirring discs peripherial speed, solids concentration and suspension throughput can be described by the specific energy (energy input per grinding feed mass in the grinding chamber). At a constant specific energy input, the product becomes finer by increasing filling ratio because in stirred media mills 
the energy is transferred from the stirrer to the suspension and the grinding media. Due to the high centrifugal forces stirred media mills usually operate with greater energy efficiency than alternative grinding devices.

The requirements for raw materials with regard to quality and reliability are constantly growing. An important step in production is the ultrafine grinding of the raw materials into the achievable final particle size. The achievable particle size distribution can in principle (throughput, peripherial speed, method of operation), by grinding media (especially diameter, density, hardness and filling ratio) and by the feed material itself (hardness, conof the particles below $5 \mu \mathrm{m}$ is required as one of the most

When grinding raw materials in stirred media mills, the the specific energy, properties of grinding beads strongly affect the grinding result. The choice of grinding beads depends on the type of the grinding material to be ground and the required fineness. As grinding media, usually beads made of glass, steel or ceramic materials are used $[9,10]$.

\section{Experiments}

The experiments were procedured by a vertical laboratory stirred ball mill. The experimental equipment (at the University of Miskolc, Dept. of Process Engineering) was operated by grinding beads in a wet process. The effective chamber volume is 0,7 litres. On the stirrer in the grinding chamber there are five fill disks with diameter of $70 \mathrm{~mm}$. The circumferential speed of disks $5,25 \mathrm{~ms}^{-1}$. The grinding media consisted of steel balls, $3.175 \mathrm{~mm}$ in diameter, with a solid density of $7800 \mathrm{kgm}^{-3}$. The stirred ball mill, filled up to $70-80 \%$ of bulk volume with the grinding medium. Water was used as carrier liquid. As grinding material, tailings of ore processing industry (from Gyöngyösoroszi, Hungary) with maximum particle size of $150 \mu \mathrm{m}$ was used. The density of solid material was $2580 \mathrm{kgm}^{-3}$. The experiments were conducted by the variation of several main parameters such as filling ratio, stirrer speed, solid mass concentration and the grinding time (see Table 1). The vertical orientation and geometry of the grinding chamber were not changed.

The variation of several main parameters by pre-grinding in the laboratory stirred ball mill [11]

Örlési paraméterek az előzetes őrlési vizsgálatok során a laboratóriumi keverőmalomban [11]

\begin{tabular}{|l|l|}
\hline Filling ratio of the mill & $\varphi_{m}=0,7-0,8$ \\
\hline Stirrer speed & $n=1440-2880 \mathrm{~min}^{-1}$ \\
\hline Solid mass concentration & $c_{m}=0,2-0,4$ \\
\hline Grinding time & $t=1-20$ minutes \\
\hline
\end{tabular}

Table 1 be influenced by design parameters (geometry of the stirrer and the grinding chamber), by operating parameters centration, density). Fineness of the ground products, most important specifications for the industrial applications. selection of grinding beads is of special significance. Besides

The product fineness was described by the characteristic particle sizes which were measured by a laser doppler sizer at the Technical University of Berlin (Sympatec Helos). Investigations showed that due to the high centrifugal forces, the particle size distribution of the ground product of the laboratory stirred ball mill was very fine. The average particle size (median) was $2,47 \mu \mathrm{m}$ (by the grinding of 20 minutes) $[11,12]$.

\section{Non-linear paramater estimation and empirical modeling}

Non-linear solutions endeavours to help process industries improve their products, materials and processes through

- better process operation, better process control

- reduced raw material consumption or energy consumption

- improved quality, reduced variations, reduced rejects

- easier product development

- improved measurement systems, software sensors

According to non-linear parameter estimations the empirical failure function can be approached. For determining the empirical failure functions, our work hypothesis is that the equipment of comminution (grinding) is firstly characterized by the shape of the breakage function. The parameters of the characteristic breakage function for given equipment depend on the main technical parameters of the mill [13].

Good nonlinear models will take into account quantitative or heuristic knowledge of the process and materials, or parts of physical models, or knowledge of some of the nonlinearities in the relations. By empirical modeling we should select the breakage function which correctly follows the particle size distribution of the product, which determines the relationship between the parameters of this function and the physical parameters of the machine: An empirical model for the estimation of particle size distributions of product has been prepared for the laboratory stirred ball mill (from pilot-scale measurements). The experiments were achieved by the optimal values of the main parameters (see Table 2). 


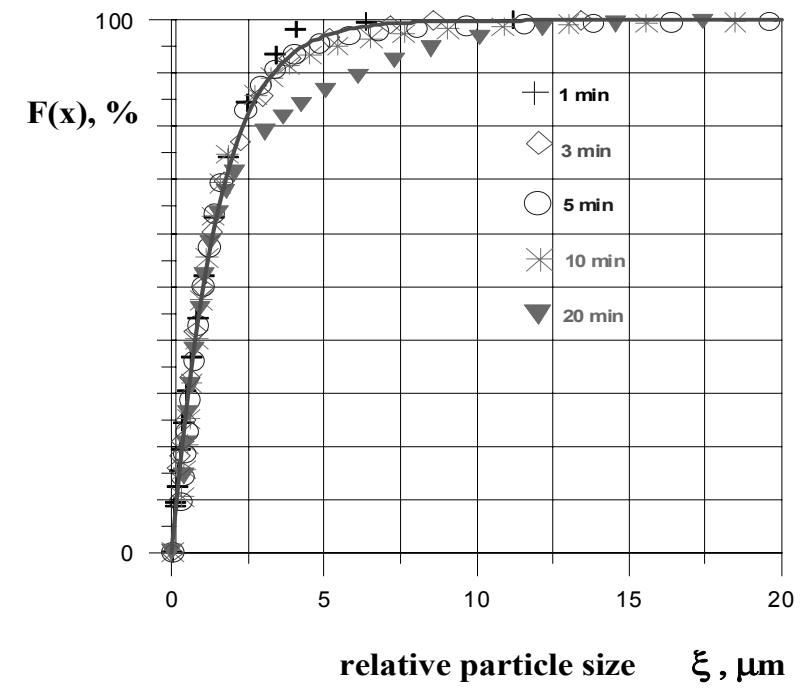

Fig. 1. Relative particle size distribution of experimental grinding mill products

1. ábra. Kisérleti örlés termékeinek relatív szemcseméret-eloszlása

The characteristics and the inner structure of the particle size distribution can be detected by the so-called characteristic or relative particle size distribution curves (these are also known as empirical failure functions) (CSÖKE, RÁCZ) [13]. Fig. 1 shows the values of the relative particle size distribution of experimental grinding mill products. Median $\left(\mathrm{x}_{50}\right)$ was used for reference particle size. (The reference particle size can be the maximum particle size or the median of the ground product). It can be noticed that the mill products are perfectly similar in their inner particle structure (they are different in the median). Most measuring points are on the same curve. The only exception is shown by the grinding product of 20 minutes where the agglutination of the particles is significant; this is called agglomeration.

Due to the results of non-linear parameter estimation the empirical failure function can be approached by adequate accuracy with Rosin-Rammler function (variance: $3,8 \%$ ).

$$
F(\xi)=1-\exp \left[-\left(\frac{\xi}{a}\right)^{m}\right]
$$

where $\zeta=\mathrm{x} / \mathrm{x}_{50}=\mathrm{f}$ (particle size, physical parameters).

The values of the parameters are: $\mathbf{a}=\mathbf{1 , 4 7 9}$ and $\mathbf{m}=\mathbf{1 , 0 3 8}$.

$$
F(\xi)=1-\exp \left[-\left(\frac{\xi}{1,479}\right)^{1,038}\right]
$$

The function parameters were also calculated by omitting the results besides the given grindig time. These parameters are: $\mathrm{a}=1,428$ and $\mathrm{m}=1,072[11,12]$.

\section{Determination of the grinding fineness and grindability}

With the given material and grinding conditions (c, $\mathrm{n}$ and $\varphi_{\mathrm{m}}=$ constant, given grinding ball size distribution and material) the grinding fineness (median) depends only on the grinding time. The relation between the grinding fineness and the grinding time was represented on a grapf for several materials such as pumice, andesite, limestone and tailings of ore processing industry (see Figure 2). The relation between the median $\left(\mathrm{x}_{50}\right)$ and the grinding time $(\mathrm{t})$ can also be given mathematically. According to the testings

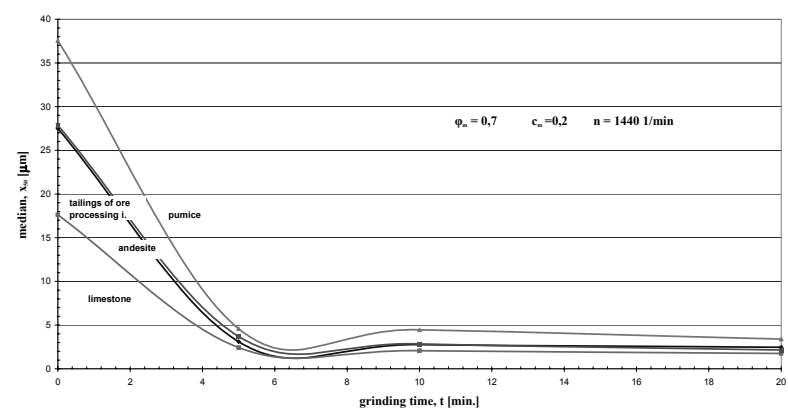

Fig. 2. Relation between the grinding fineness and the grinding time for several materials

2. ábra. Közepes szemcseméret változása az örlési idö függvényében

$$
x_{50}=a \cdot t^{b}
$$

power function gives the most punctual correlation. From the data of the measurements $[11,12]$ :

$$
\mathrm{x}_{50}=7,355 \mathrm{t}^{-0,405}
$$

The constants $\boldsymbol{a}$ and $\boldsymbol{b}$ can be determined:

$$
a=f\left(n, c_{m}, \varphi_{m}\right), \quad b=f\left(n, c_{m}, \varphi_{m}\right)
$$

The relation between the grinding fineness and the specific grinding work $\left(W_{f}\right)$ was described for several materials mathematically. According to the testings the grinding fineness can be determined by the grindability index number (parameter $C_{m i x}$ ) and the exponent $m$ (see Table 3).

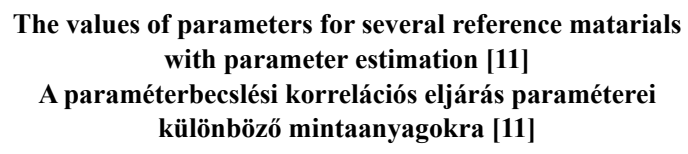

\begin{tabular}{|l|l|l|l|}
\hline Reference matarial & Cmix & $m$ & $\begin{array}{l}\text { Scattering/correlation } \\
\text { index, } \sigma / R\end{array}$ \\
\hline pumice & 15,32 & 0,198 & $0,0470 / 0,997$ \\
\hline andesite & 11,07 & 0,204 & $0,01505 / 0,992$ \\
\hline limestone & 7,38 & 0,190 & $0,00205 / 0,999$ \\
\hline $\begin{array}{l}\text { tailings of ore } \\
\text { processing industry }\end{array}$ & 14,45 & 0,230 & $0,0052 / 0,9995$ \\
\hline
\end{tabular}




$$
x_{50}=\frac{C_{m i x}}{W_{f}^{m}}
$$

According to Table 3 the value of the exponent $m$ (angular coefficient) for several reference materials is constant, this is 0,2 . According to the grindability index number $\left(C_{m i x}\right)$ the grindability sequence is: limestone, andesite, tailings of ore processing industry and pumice. The relation between the grinding fineness and the specific grinding work is showing equal principle for all tested materials (see Figure 3) [11].

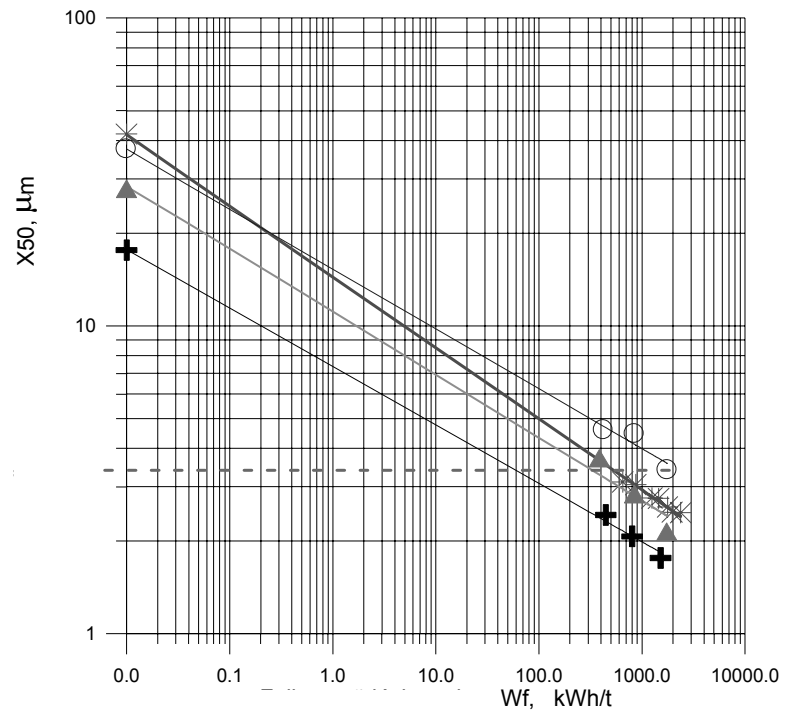

Fig. 3. Relation between the grinding fineness and the specific grinding work for several materials

3. ábra. Örlési finomság a fajlagos örlési munka függvényében különbözö mintaanyagokra

\section{Conclusions}

The verification of the grindability of several materials is achievable with ultrafine grinding in the scale stirred ball mill. The particle size distribution of mill products can be well estimated by empirical modell. These empirical functions represent the dependence of the parameters of functions on the mill characters (mainly $n, c_{m}, \varphi_{m}, d_{g}$ ). The pattern behaviour of the grinding process in the stirred ball mill that can be characterized by two basic functions: the relative particle size distribution function that is currently a Rosin-Rammler shaped empirical failure function and the function that describes the change of median that is currently $x_{50}=f(t)$ power function. The relation between the grinding fineness-grinding time and the grinding fineness-specific grinding work can be given mathematically. The grindability index number (parameter $C_{\text {mix }}$ ) can be indicated for the description of the grindability in stirred ball mills. The value of parameter $m$ for the several materials is constant: 0,2 . According to $C_{m i x}$ the grindability sequence is: limestone, andesite, tailings of ore processing industry and pumice.

\section{ÖSSZEFOGLALÁS}

A diszperz rendszerek előállításánál az aprítás és az őrlés az egyik leggyakrabban alkalmazott technológiai müvelet. Ma már bizonyított, hogy az örlés a részecskeméret csökkenése mellett, az örleményben mélyrehatóbb szerkezeti változásokat és kémiai átalakulásokat is előidéz. A finomőrlés során végbemenő anyagszerkezeti változások és mechanokémiai reakciók szempontjából a plasztikus (mikroplasztikus) deformáció létrejötte játszik fontos szerepet, ahol a részecske gyakorlatilag ,hibahelymentessé” válik. A finomőrléssel előállított termékek tulajdonságait az elsődleges és a másodlagos mechanokémiai folyamatok sebessége és mértéke határozza meg. Az őrlési folyamatot az elsődleges folyamatok elősegítésével és a másodlagos folyamatok visszaszorításával lehet irányítani. Hazánkban, a finomőrlés hatékonyságának mechanokémiai kidolgozásában JUHÁSZ és OPOCZKY [1, 2, 3, 4] ért el úttörö eredményeket. A finomőrléskor jelentkező mechanokémiai jelenségek kollerjáraton történő tanulmányozásával GÖMZE $[5,6,7]$ foglalkozott.

Az anyagoknak keverőmalomban történő örölhetőségének megállapítása céljából kutatásaim során, egy saját tervezésű laboratóriumi keverő-golyósmalommal végeztem ultrafinom nedves őrlési vizsgálatokat. Az őrlemény szemcseméret-eloszlásának becslése empirikus modell segítségével történhet. A keverőmalmi őrlési folyamat törvényszerü viselkedése két alapfüggvénnyel jellemezhető: az empirikus törési függvénnyel és az $x_{50}$ időbeli változását leíró $x_{50}=a \cdot t^{b}$ (medián-őrlési idő) hatványfüggvénnyel. Az alapfüggvények paramétereinek az üzemjellemzőktől (n, $\mathrm{c}_{\mathrm{m}}, \varphi_{\mathrm{m}}, \mathrm{d}_{\mathrm{g}}$ ). való függését reprezentáló empirikus függvények alkalmazásával az őrlemény szemcseméret-eloszlás jól megbecsülhető. Az elvégzett (nemlineáris paraméterbecslési) korrelációs eljárással kapott eredmények szerint, a törési függvény Rosin-Rammler függvénnyel, elegendő pontossággal közelíthető. A medián és a fajlagos őrlési munka közötti összefüggés valamennyi vizsgált anyagra azonos törvényszerüséget mutat, ahol az $m$ kitevő (meredekség) 0,2 konstans érték. A $C_{m i x}$ paraméter az őrölhetőséget jellemző mérőszám, amelynek alapján a keverőmalomban vizsgált anyagok örölhetőségének sorrendje (a könnyebben őrölhetőtől a nehezebben őrölhető felé haladva): mészkő, andezit, gyöngyösoroszi meddö és pumicit.

\section{Formula index}

\begin{tabular}{|l|l|l|}
\hline Symbol & Unit & Description \\
\hline $\mathrm{c}_{\mathrm{m}}$ & - & solid mass concentration \\
\hline $\mathrm{n}$ & $\min ^{-1}$ & stirrer speed \\
\hline $\mathrm{t}$ & $\mathrm{min}$ & grinding time \\
\hline $\mathrm{x}_{50}$ & $\mu \mathrm{m}$ & median \\
\hline$\varphi_{\mathrm{m}}$ & - & filling ratio of the mill \\
\hline$\xi$ & $\mu \mathrm{m}$ & relative particle size \\
\hline $\mathrm{a}, \mathrm{b}$, & - & constants \\
\hline $\mathrm{a}, \mathrm{m}$ & - & exponents \\
\hline
\end{tabular}




\section{References}

[1] Juhász, A. Z.: A finomőrlés fizikokémiai vonatkozásai-Örlésfizikai és mechanokémiai kutatások. Építőanyag 50. évf., 1998/4, pp. 134 138.

[2] Juhász, A. Z., Opoczky, L.: Szilikátok mechanikai aktiválása finomőrléssel. Akadémiai Kiadó. Budapest, 1982.

[3] Juhász, A. Z., Opoczky, L.: Mechanokémia és agglomeráció. Építöanyag 55. évf., 2003/3, pp. 86-90.

[4] Opoczky, L, Gável, V.: A különőrlés előnyei kompozicementek előállításánál. Építőanyag 55. évf., 2003/1, pp. 2-7.

[5] Gömze, A. L.: Az aprítás elmélet néhány aktuális kérdése - képlékeny viszkoelasztikus anyagok aprítása görgőjáraton. Építőanyag 55. évf., 2003/4, pp. 133-140.

[6] Gömze, A. L.: Kollerjáratok energiaigénye I. Bányanedves agyagásványokban aprításkor ébredő csúsztatófeszültség előállításához szükséges energia- és teljesítményfelvétel meghatározása. Építőanyag 56. évf., 2004/2, pp. 46-53.

[7] Gömze, A. L.: Kollerjáratok energiaigénye II. Bányanedves agyagásványokban aprításkor ébredő nyomófeszültség előállítá- sához szükséges energia- és teljesítményfelvétel meghatározása. Építőanyag 56. évf., 2004/3, pp. 93-100.

[8] Stehr, N.: Zerkleinerung und Materialtransport in einer Rührwerkskugelmühle. Dissertation. TU Braunschweig, Germany, 1982.

[9] Karbstein, H., Müller, F., Polke, R.: Scale-up for Grinding in Stirred Ball Mills. Aufbereitungs-Technik 37 (1996) Nr. 10, pp. 469-479.

[10] Becker, M., Kwade, A.: Feinstzerkleinerung keramischer Rohstoffe und Mahlkörperverschleiss in Rührwerkmühlen. AufbereitungsTechnik 38 (1997) Nr. 8, pp. 430-438.

[11] Mannheim, V.: Wet Fine Grinding of Tailings of Ore Processing for Physical Digestion. Dissertation, University of Miskolc, Hungary, 2005.

[12] Mannheim V.: Scale up for ultrafine grinding in stirred ball mill and empirical estimation of the particle size distribution of ground, „11 th European Symposium on Comminution". Budapest (Hungary), 2006 (CD ROM).

[13] Csöke, B., Rácz, J.: Estimation of the Breakage and Selection Function for Comminution in Hammer Mill. " 9 th European Symposium on Comminution". Albi (France), 1998, pp. 393-401. 